\title{
Traditional ecological knowledge reveals the extent of sympatric lake trout diversity and habitat preferences
}

\author{
Kia Marin $^{1}$, Andrew Coon $^{2}$ and Dylan J. Fraser ${ }^{1}$
}

\begin{abstract}
Multidisciplinary approaches to conservation have become increasingly important in northern regions. Because many First Nations communities have relied on freshwater fish populations for essential food over millennia, community members often possess traditional ecological knowledge (TEK). We consulted Cree First Nation fishers to collate TEK for one of Canada's most important subsistence fishes (lake trout) in Québec's largest lake (Mistassini, $2335 \mathrm{~km}^{2}$ ). We further integrated TEK with what was regionally known scientifically about the species, toward effective fisheries conservation. Cree fishers described a richer diversity of sympatric lake trout forms than did scientific research that was conducted simultaneously, based on color, size, fin accent patterns, scale texture and depth, and spatial preferences. Traditional ecological knowledge also provided descriptions of lake trout seasonal movements, spawning locations, and reproductive timing that were not captured by scientific research, and highlighted several concerns or temporal changes of import to future management initiatives. Our study highlights the wealth of TEK on harvested species in First Nations communities. It further illustrates how TEK can reveal not only distinctions within species of relevance to natural resource management and taxonomy, but also informs upon the extent of such population differentiation, thereby providing important conservation benefits for remote and northern regions.
\end{abstract}

Key Words: Cree; First Nations; lake trout; Mistassini Lake; population differentiation; Salvelinus namaycush; TEK; traditional ecological knowledge

\section{INTRODUCTION}

Multidisciplinary approaches that incorporate traditional and scientific knowledge are increasingly being adopted to better understand, manage, and conserve biodiversity and natural resources (Drew and Henne 2006, Fraser et al. 2006, Mehring et al. 2011, Ruiz-Mallén and Esteve 2013). Such approaches are particularly attractive in northern regions, where effective longterm monitoring based solely on western science can be very challenging for economic and logistic reasons, and where sampling or monitoring can be conducted only intermittently or seasonally (Ferguson and Messier 1997, Berkes 2012, Thornton and Scheer 2012, Polfus et al. 2014). The success of multidisciplinary conservation projects, in turn, often requires that a diverse group of people work together and share their knowledge toward achieving a common goal (Braun 2002, Harris 2003, Drew and Henne 2006, Huntington et al. 2011, Jackson et al. 2014).

Local people who live or work closely with the natural environment (e.g., hunters and trappers, fishers, farmers) often develop extensive local ecological knowledge (Berkes et al. 2000). Consulting local people for this knowledge has become increasingly important for conservation planning (e.g., ParradoRosselli 2007, Murray et al. 2008, Gaoue and Ticktin 2009, Stacey et al. 2012), especially in many northern regions (e.g., Kendrick and Manseau 2008, Brook et al. 2009, Henri et al. 2010, Mustonen and Feodoroff 2013, Polfus et al. 2016). This detailed, cumulative, and often dynamic knowledge of both past and present ecological systems has been termed "traditional ecological knowledge" (TEK) (Gadgil et al. 1993, Inglis 1993, Huntington 2000, Menzies and Butler 2006). It is defined as the "cumulative body of knowledge, practice, and belief, evolving by adaptive processes and handed down through generations by cultural transmission, about the relationship of living beings (including humans) with one another and with their environment" (Berkes et al. 2000: 1287). In particular, TEK has successfully supplemented and complemented western science toward more effective conservation planning and implementation in local fisheries management (Aswani and Hamilton 2004, Fraser et al. 2006, 2013, McGoodwin 2006, Menzies and Butler 2006).

The James Bay Cree (Eeyouch) are a group of 18,000 indigenous people who inhabit eastern James Bay and southern Hudson Bay in northern Québec, Canada (GCC 2015). Nine Cree communities are situated on $450,000 \mathrm{~km}^{2}$ of traditional territory (Eeyou Istchee, "The People's Land") (GCC 2011). Respect and gratitude are two fundamental aspects that shape the Cree's relationship with their natural environment (Cree Culture Institute 2015). Water (neebee) is imperative for the health, productivity, and integrity of the sub-Arctic environment as a whole, and fish (namesh) are part of Cree daily lives (GCC 1999). During times of starvation or when large game was scarce, fish were the only reliable natural resource for the Cree (GCC 1994, Berkes 2012). For millennia, the Cree have lived off the land by hunting, trapping, and fishing for subsistence, economic, and cultural reasons. As such, they possess a great knowledge of their territory that has been passed down through the generations, particularly with regard to fish movement, distribution, and seasonal cycles (Fraser et al. 2006, 2013, Berkes 2012).

Mistissini (Cree for "big rock") is one of nine James Bay Cree communities and is situated on the southeastern coast of Mistassini Lake, Québec's largest natural lake $\left(2335 \mathrm{~km}^{2}\right)$ and one of its deepest (180 m) (Statistics Canada 2005) (Fig. 1). Mistassini Lake has been largely unaffected by human activity and harbors a variety of freshwater fishes. Many of these species hold 
historical and contemporary importance, both socioeconomically and culturally, because they are targeted by Cree subsistence fishers and by sport fishers who fish from local Cree-operated outfitting camps, the community of Mistissini, and the Réserve Faunique des Lacs Albanel Mistassini-et-Waconichi. Previous brook trout (Salvelinus fontinalis) studies successfully integrated TEK from local fishing experts to provide information that was not captured in scientific studies on the persistence of populations, breeding areas, and temporal trends in fishing efficacy, and life history characteristics over four decades (Fraser et al. 2006, 2013). The research identified local conservation concerns while developing a collaborative relationship necessary for long-term fisheries monitoring (Fraser et al. 2006, 2013).

Fig. 1. Geographic location of Mistassini Lake, Québec showing examples (inset photos) of the lake trout variations and their geographical summer distribution (colored ellipses) as described by multiple Cree First Nation fishers.

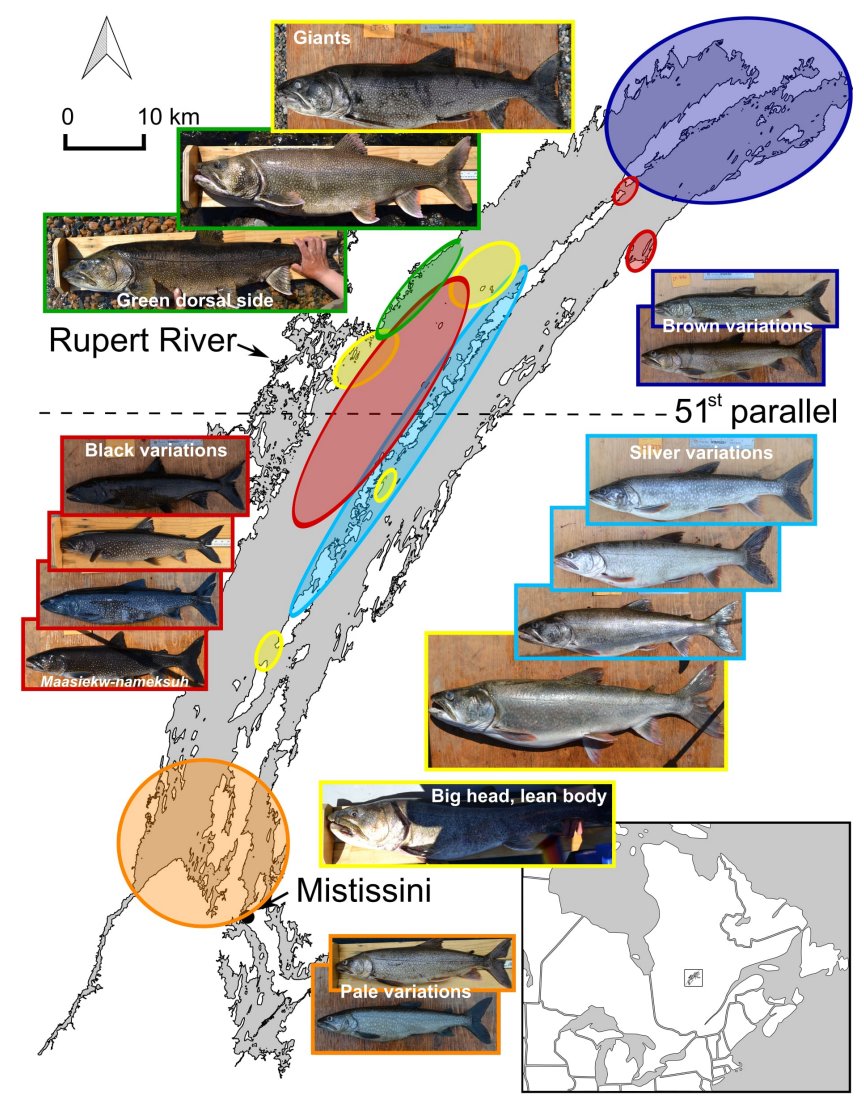

Although lake trout (Salvelinus namaycush), a large-bodied terminal predator fish of North American postglacial lakes, is one of the most harvested species in Mistassini Lake and northern Canada (Fraser et al. 2006, DFO 2012), there have been few attempts to formally document what local indigenous communities know about the species. Large postglacial lakes such as Mistassini are of particular interest because their diverse habitats commonly favor the evolution of sympatric forms of freshwater fishes that are differentiated genetically, morphologically, and ecologically (Taylor 1999, Klemetsen 2010, Fraser et al. 2013).
Recognizing and maintaining such sympatric diversity has important practical implications because it may be linked to longterm species persistence, increased yield, and reduced annual variability in productivity (Schindler et al. 2010). In Mistassini Lake, human-related development, population growth, and fishing pressures have increased over the past decade (Fraser et al. 2006, Statistics Canada 2011). These increases have resulted in a growing need to expand upon limited and preliminary scientific knowledge of lake trout by compiling TEK, toward ensuring the persistence and sustainability of the species.

Until very recently, little was known scientifically about Mistassini lake trout. Dubois and Lagueux (1968) documented the age and size of lake trout from unknown localities. Zimmerman et al. (2007) identified two forms that differed in age, growth, and maturity (Hansen et al. 2012) in a small area of the lake. Most recently, Marin et al. (2016) sampled the entire lake and used morphological and DNA analyses to determine that Mistassini harbors at least five weakly differentiated subpopulations of sympatrically occurring lake trout with striking phenotypic variation, including differences in body size, coloration, and to a lesser extent, body depth, caudal peduncle size, eye position, and head shape. Subpopulations were captured in different lake basins and localities, and exhibited depth and prey preferences, but were also observed to disperse great distances and to change depths regularly (Marin et al. 2016). However, all scientific research conducted to date on Mistassini lake trout has been restricted to a short period of summer sampling and has not been temporarily replicated. It was unknown whether distinct lake trout forms were recognized similarly by the Cree, how these forms were harvested, if different spatial distributions of these forms were recognized, and/or if any temporal changes in Mistassini lake trout abundance and distribution had occurred over the past several decades.

Our main objectives were to compile TEK on sympatric lake trout in Mistassini Lake to (1) expand upon existing local scientific knowledge of the species, (2) document any temporal changes in lake trout biology and abundance, and (3) assist in identifying local concerns that might aid in local conservation plans and practices. To collate TEK, we conducted collaborative fieldwork and semidirected interviews with local Cree Nation of Mistissini fishers in the summers of 2013 and 2014. Based on previous TEK studies of Mistassini Lake fishes (Fraser et al. 2006, 2013), we anticipated that local fishing experts would be able to provide details on lake trout variation and temporal trends in habitat use, distribution, and abundance.

\section{METHODS}

\section{Collaborative fieldwork}

Our collaborative fieldwork with Cree Nation of Mistissini fishers and community members allowed for the collation of TEK of Mistassini lake trout over an extended period of two months in the summer of 2013. Because our scientific research included sampling and photographing trout with local fishing guides and community members at a local outfitting camp (Marin et al. 2016), interactions occurred on a regular basis. Multiple interactions daily lasted anywhere from 5 (e.g., collection of a sample) to 60 minutes (e.g., discussion over a meal), and notes were recorded in a notebook. Traditional ecological knowledge 
Table 1. Series of questions used for semidirected interviews with peer-reference experts.

\begin{tabular}{ll}
\hline \hline Subject & General questions \\
\hline General informant information & How many years have you been fishing on Mistassini Lake? \\
Ecology & When do you typically fish for lake trout? \\
& Where do you typically fish for lake trout? \\
& What do you use to capture lake trout? \\
& At what depth do you capture lake trout? \\
& Are there differences between lake trout in the west and east basins, shallow and deep water and north and \\
& south tributaries? \\
& Can you describe what lake trout look like that you capture? \\
Morphology & Have you seen lake trout that look like this? \\
& If yes, can you please describe/show me where and when do you capture them? \\
& Can you describe any other colors, shapes, or kinds of lake trout not seen in this picture? \\
& Do you know when and where lake trout spawn? \\
If yes, can you describe/show their location? & If yes, do all lake trout that you described earlier spawn in the same location? \\
Spawning & Have you noticed any changes to lake trout on the lake since you've been fishing? \\
& If yes, do you know what might be causing these changes? \\
Conservation & If yes, when did you notice these changes? \\
& Have the numbers of lake trout decreased, increased, or remained the same over the years you have been \\
& fishing? \\
& Do you have any overall concerns about the health of lake trout in Mistassini Lake? \\
What factors might contribute to short-term changes to the number of lake trout there are? & What factors might contribute to where lake trout move/inhabit the lake? \\
What do you think can be done to protect lake trout population for future generations?
\end{tabular}

obtained through collaborative fieldwork was not gathered from structured questions but instead from observations and knowledge possessed by individuals.

\section{Semidirected interviews}

We also collected TEK on lake trout from local fishing experts through semidirected interviews in the summers of 2013 and 2014. We considered experts as informants from the local community of Mistissini who had more than 20 years of fishing experience on Mistassini Lake. The local Cree Trapper's Association, local fishers, and community members helped us identify informants who had the most knowledge about lake trout. In total, 18 experts were identified from the community of Mistissini via such peerreferencing (Davis and Wagner 2003). Multiple attempts were made to screen all 18 identified experts; however, due to logistical or seasonal reasons, and in one instance resistance, 15 of the 18 experts identified were interviewed $(>80 \%)$.

The informants were Cree elders, fishers, and/or tallymen who had long-term knowledge of Mistassini lake trout, based on an average of 31 years of fishing experience (range 20-49 years). Interviews took place at the local outfitting camp, the informant's home, or in the Tourism Office in Mistissini. Interviews lasted between 30 and 90 minutes and were guided by the interviewer with a series of questions (Table 1); however, the interview was free to flow with the informant's observations and stream of consciousness (Huntington 2000). Major advantages of such semidirected interviews include flexibility based on each informant's observations, provision of supplementary information not expected by the interviewer, and freedom of influence of other individuals (Ferguson and Messier 1997, Huntington 2000).

Each interview began by outlining the interview objectives and procedures. Each informant was told that the information they provided would be compiled into a report for future lake trout management and conservation, and that their specific points would remain anonymous; oral consent was obtained from the informants. Oral interviews were appropriate for our research because some participants were not able to read or write in English, French, or Cree. Visual aids, such as maps of Mistassini Lake and photos of lake trout taken throughout the fieldwork, were used in conjunction with specific questions. Informant discussion was recorded in a notebook by the interviewer and was not audio-recorded. Informants were free to answer questions in Cree, English, or French, and local expressions were clarified by a third-party translator. Collection of TEK from 15 experts, both via collaborative fieldwork and semidirected interviews, was approved by Concordia University's Human Research Ethics Committee (protocol \#30003281).

\section{RESULTS}

\section{Summary of traditional ecological knowledge on lake trout biology}

General spatial and depth locations of the species

Lake trout are captured throughout Mistassini Lake in a number of known locations based on seasonal changes (Table 2). During winter, a few informants used gillnets to capture trout in shallow waters at the southern end of the lake. As the water warms and the ice melts, trout can be found throughout the lake, again in shallow waters. The most common time of year to capture lake trout, as described by informants, was from mid-June and throughout July in deeper water. Most informants (14 of 15) described various locations in the western basin of Mistassini Lake in which lake trout were abundant and easy to capture via gillnet, nightlines, or angling methods. Commonly, the western basin was regarded as harboring more productive lake trout 
Fig. 2. Findings from Marin et al. (2016) showing that genetically distinct subpopulations (A) 1 and 5 were captured in significantly greater numbers in the eastern basin, whereas subpopulations 3 and 4 were more predominant in the western basin; (B) subpopulation 1 was found in deep water, 4 was found mid-depth, and 2, 3 , and 5 were captured in shallow water; (C) subpopulations 2, 3, and 5 were predominately black, whereas 1 and 4 were a mix of both dark and light coloration; (D) results of a spatial principal component analysis showing that individual lake trout are more closely related than by random chance in the western basin adjacent to the mouth of the Rupert River compared with those in the northern passage.

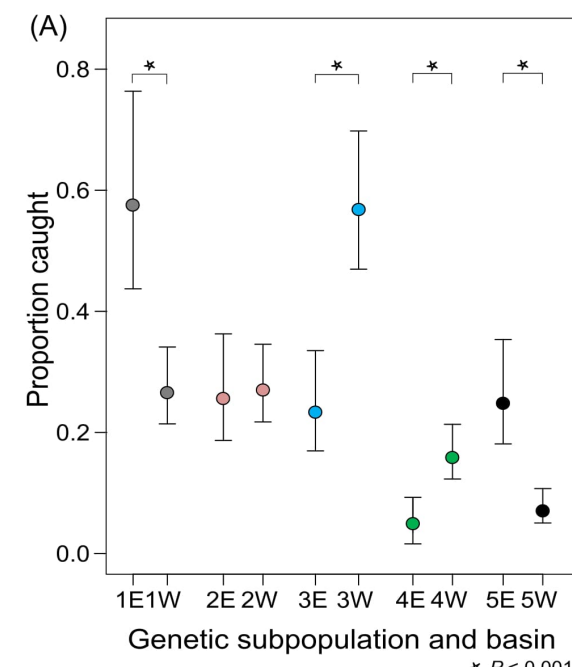

(B)
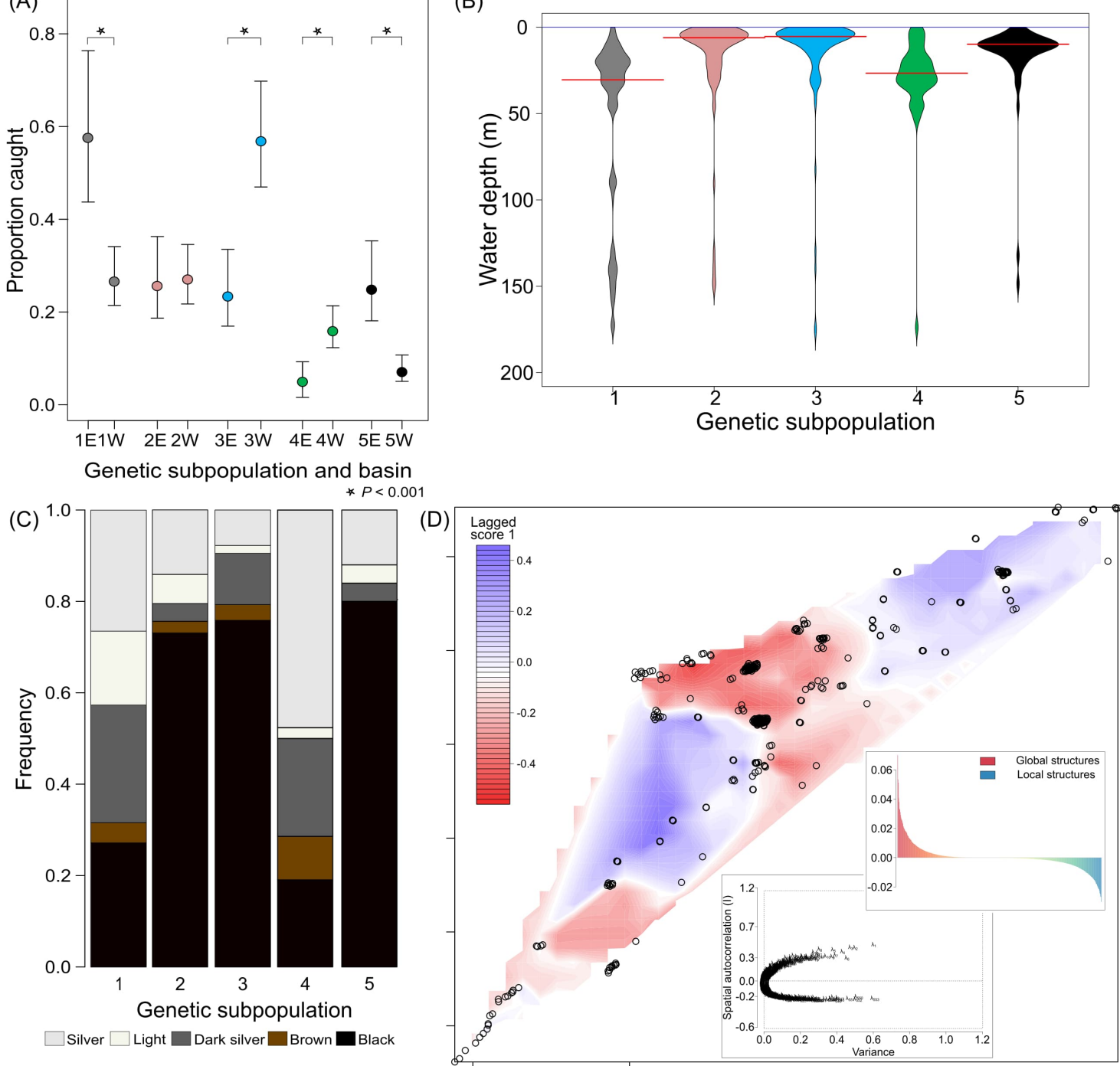

fishing than was the eastern basin in terms of numbers and average trout size, perhaps due to prey abundance, water temperature, and/or available habitat (Table 2). Concurrent with scientific findings from Marin et al. (2016), trout from genetically defined subpopulations (\#3, 4) of larger body size were captured predominately in the western basin (Fig. 2A). Lake trout are nonetheless found throughout the eastern basin, but only six informants reported fishing there for this species, of which three found lake trout more difficult to catch in the eastern than the western basin.
Morphological diversity

All informants described several different lake trout forms in Mistassini Lake, based most often on color and/or size (Fig. 3, Table 2). Almost all informants (14 of 15) were familiar with small $(1.4-2.3 \mathrm{~kg})$, black forms, and giant $(>3.6 \mathrm{~kg})$ forms with various colors; fewer informants described lake trout that were silver or grey. Informants also described green, brown, light, and pale forms of lake trout (Table 2). Additionally, informants described other aspects of morphology, such as trout with pointed snouts (that eat other fish), or "with big spots - they are the ones that 
Table 2. Overall ecological and morphological diversity of lake trout in Mistassini Lake as described by local experts.

\begin{tabular}{|c|c|c|c|}
\hline \multicolumn{2}{|l|}{ Observation/description } & Informant & Freq. (/15) \\
\hline \multicolumn{4}{|c|}{ Ecology - where lake trout are primarily captured } \\
\hline May-early June & Shallow shorelines throughout the lake & $1-4,7,9,10,13,14$ & 9 \\
\hline \multirow{6}{*}{$\begin{array}{l}\text { Aug.-Sept. } \\
\text { Winter }\end{array}$} & $\begin{array}{l}\text { Western basin (from island chain to western shoreline) but not in } \\
\text { the shallows }\end{array}$ & $1-3,5-15$ & 14 \\
\hline & Eastern basin & $5,7,9,13,15$ & 5 \\
\hline & North passage & $1-6,10,13-15$ & 10 \\
\hline & North end & 6,10 & 2 \\
\hline & Western shoreline shallows & $4-8,10,11,13,14$ & 9 \\
\hline & South end shallows & $4,10,13$ & 3 \\
\hline \multicolumn{4}{|c|}{ Morphology - variety of morphs described } \\
\hline \multirow{2}{*}{\multicolumn{2}{|c|}{$\begin{array}{l}\text { Big head and lean body } \\
\text { Black, small }(1.6-2.3 \mathrm{~kg})\end{array}$}} & 3,13 & 2 \\
\hline & & $1-15$ & 15 \\
\hline \multicolumn{2}{|c|}{ Black with faded spots, small $(1.4-2.3 \mathrm{~kg})$} & $2,4,8,9$ & 4 \\
\hline \multicolumn{2}{|l|}{ Brown } & 7,13 & 2 \\
\hline \multicolumn{2}{|c|}{ Dark brown with light belly } & 7,13 & 2 \\
\hline \multicolumn{2}{|c|}{ Giant $(>3.6 \mathrm{~kg}$ ) of various colors } & $1-14$ & 14 \\
\hline \multicolumn{2}{|c|}{ Green dorsal side } & 1,7 & 2 \\
\hline \multicolumn{2}{|c|}{ Light colored and deep bodied } & 1,4 & 2 \\
\hline \multicolumn{2}{|c|}{ Maasimekw-namekush (brook trout-like lake trout) } & 1 & 1 \\
\hline \multicolumn{2}{|c|}{ Silver/grey } & $1,2,3,5-10$ & 9 \\
\hline \multicolumn{2}{|c|}{ Silver/grey with big spots, big head, and red/yellow-tipped fins } & $2,7,10$ & 3 \\
\hline \multicolumn{4}{|c|}{ Spawning - location and timing } \\
\hline \multicolumn{2}{|c|}{ Western shoreline in shallow water $(0-6.1 \mathrm{~m})$} & $1,2,3,4,6,8$ & 6 \\
\hline \multicolumn{2}{|c|}{ Shallow areas but not exclusively the western shoreline } & 3 & 1 \\
\hline \multicolumn{2}{|c|}{ Late August - September } & 1 & 1 \\
\hline \multicolumn{2}{|c|}{ Different morphs spawn in different areas } & 1,15 & 2 \\
\hline
\end{tabular}

get big" (Informant 2). Even descriptions of black forms varied from very black with spots that are hard to see, to black with identifiable spots and yellow-tipped fins, to maasimekw-namekush (brook trout-like), where the caudal fin was not as deeply forked and both the texture of the scales and flesh color (pink) were different from typical lake trout.

Fig. 3. Frequency of discernible lake trout morphological variants described by Cree First Nation fishing experts grouped by color (DS = dark silver).

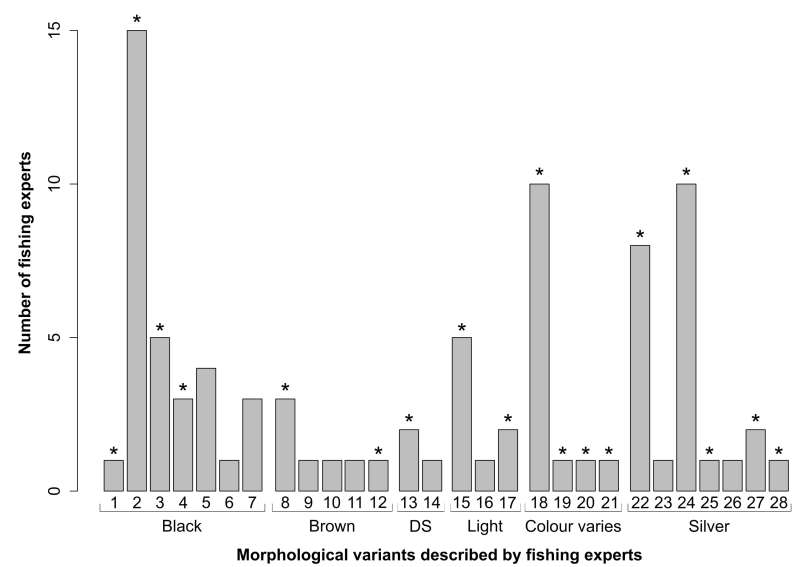

*Captured during fish study (June, July 2013
When informants were shown a collage of various lake trout caught throughout Mistassini Lake (Fig. 4), only three (of 15) recognized fish that primarily occupy deeper water $(>61 \mathrm{~m})$ and were discovered to be genetically related as a subpopulation (Marin et al. 2016) (Fig. 2B). We suspect this infrequent sighting is because informants set gillnets only to a maximum of $61 \mathrm{~m}$. Moreover, informants stated that these specific lake trout were not targeted for harvesting due to their small size and low fat content. One of the three informants who recognized the deeper water form also noted that such trout usually have large caudal fins.

Fig. 4. Collage of photographs of various lake trout taken in June 2013 and shown to Cree First Nation fishing experts as part of semidirective interviews.

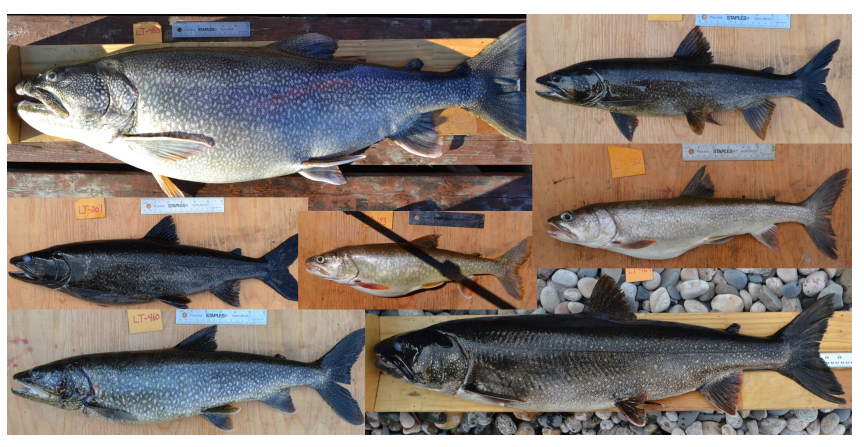


Overall, 28 discernible lake trout variations were described by informants, six of which were consistently ( $\geq 5$ informants) described; others were mentioned by one informant only (Fig. 3). Previous scientific research based on geometric morphometric analyses identified three distinct body shapes, five distinct head shapes, and five general colors of Mistassini lake trout (Marin et al. 2016). Given such vast phenotypic diversity, we suspect that even more morphological variation might exist in sympatrically occurring lake trout of Mistassini Lake than has been documented to date.

\section{Spatial and depth preferences of different lake trout forms}

Informants described summer habitats and depths at which they typically captured different lake trout forms (Fig. 1). Specifically, black forms (with various spot patterns) were typically captured in open water between 0 and $6 \mathrm{~m}$ in the western basin. Some informants also described capturing giant forms at greater depths (between 12 and $30 \mathrm{~m}$ ) and commonly on steep drop-offs in specific areas within the western basin. The Rupert River, Mistassini Lake's outflow, is located just above the 51st parallel on the western shoreline of the lake (Fig. 1). Lake trout captured at the Rupert River mouth and within the river itself were described by some informants (4 of 15) as bigger or fatter (2.7$3.6 \mathrm{~kg}$ ) and with a different appearance (e.g., grey, with large white spots and scratch marks from bumping into rocks). Lake trout forms described by 8 of 15 informants as being grey/silver (with varying head shape/size, spot pattern, and fin accent colors) were associated with medium depths $(6-15 \mathrm{~m})$ and the center chain of islands that runs down the length of the lake (Fig. 1). Finally, small- or medium-sized brown lake trout were most closely associated with the northern end of the lake, while medium-sized paler individuals were associated with the southern end (closer to the community of Mistissini).

Descriptions of habitat and depth preferences gathered through TEK were largely congruent with what has been documented scientifically on Mistassini lake trout (Zimmerman et al. 2007, Marin et al. 2016). Notably, Marin et al. (2016) typically found that dark lake trout resided in shallow water, and giant forms were located on steep drop-offs, predominantly in the western basin (Fig. 2A,C). However, Marin et al. (2016) did not capture many brown trout in the northern end of the lake that were larger than $1.4 \mathrm{~kg}$, and captured very few pale trout in the southern end of the lake.

Many informants also depicted seasonal changes and movements of different lake trout forms. Specifically, Mistassini Lake forms typically move great distances throughout the year, both vertically in the water column and throughout the lake. Multiple informants (6 of 15) described capturing black, brown, silver, and giant forms in shallow water during the winter; silver and black forms along the shorelines of the north, center chain of islands, and western side of the lake ( 8 of 15 ); and multiple forms in deeper waters in the center of lake basins during summer (10 of 15). Congruent with Marin et al. (2016), lake trout from each of the morphological clusters and genetic subpopulations were captured throughout the lake in June and July.

\section{Timing and location of lake trout reproduction}

Lake trout spawning locations and timing were fairly consistently detailed by the informants; however, specific details were kept to a minimum. These locations may be well known among local fishing experts, but most informants were keen to keep the specific locations to themselves. All informants depicted lake trout spawning in shallow water (0-6 m) any time between late August and the third week of September (Table 2). Eight of 15 informants described locations on the western shoreline of the western basin, whereas fewer informants (5 of 15) described additional areas (e. g., both west and east shorelines of the chain of islands, and eastern basin). Only a few informants ( 2 of 15 ) noted that different forms spawn in different locations.

\section{Cree concerns regarding the status of lake trout populations in Mistassini Lake}

Informants raised several concerns regarding the conservation of lake trout forms in Mistassini Lake (Table 3). Perspectives on trends in lake trout abundance were split: 8 of 15 informants felt that Mistassini's lake trout population has been stable over the last 30 years, whereas 7 of 15 noted a decrease in overall abundance over the last 40 years. Other concerns included the following: (1) spawning occurring 1-2 weeks later and in deeper water; (2) a decrease in the number of large (2.3-4.5 kg) and an increase in the number of small $(0.9-2.3 \mathrm{~kg})$ lake trout on spawning grounds; (3) morphological changes, including fewer observations of deep-bodied, large lake trout (i.e., big bellies); and (4) behavioral changes, such as a decrease in the number of lake trout breaching during the summer months. While there were mixed concerns regarding temporal population trends, most informants expressed trepidation about the general decrease in fishing efficiency, increase in overfishing, increase in the number and size of boats, and increase in the number of people on the lake over the past $10-40$ years.

Multiple informants also described how different fishing methods have changed over time. For example, every generation of Cree fishers has used gillnets. In the past, fishers would remove a net, consume the fish, and then reset the net once they required more fish for subsistence. Today, as one informant stated, the mentality has changed - a gillnet is hauled, fish are removed, and the net is set back immediately. This activity was often perceived as overexploitation and harmful, especially in one location or habitat. Over the last decade, the Mistassini Lake region has seen human population growth, which has brought with it economic development (Statistics Canada 2011). As such, mining exploration and exploitation, logging, and hydro projects have occurred within Mistissini's traditional Cree territory, as well as increased tourism and numbers of sport fishers on the lake (A. Coon, personal communication, 2013). Many informants ( 7 of 15) conveyed concerns regarding the potential changes to the Mistassini Lake environment, including potential pollution or contamination from human activities, and the threat of possible invasive species.

Multiple seasonal changes have also been observed over the last 40 years, including fluctuations in Mistassini's water level due to varying amounts of winter precipitation, changes in movement of lake trout, and fluctuations in prey abundance. While descriptions of seasonal lake trout movements were common, multiple ( 3 of 15) informants commented that in some years, lake trout (and even their conspecifics and/or prey) were not as easily captured in places where they were previously known to have been plentiful (Table 3 ). These changes, as described by one informant, were not due to changes in overall lake trout abundance but merely 
Table 3. Local Cree concerns related to lake trout conservation and management according to local experts (ML $=$ Mistassini Lake).

\begin{tabular}{|c|c|c|c|c|}
\hline Observation & Trend & Timeline & Informant & Freq. (/15) \\
\hline Population & Decreasing & Past 40 years & $2,3,6-8,13$ & 6 \\
\hline Population & Stable & Past 30 years & $1,4,5,9-12,14-15$ & 9 \\
\hline Spawning timing & Later & Past 10 years & 4,5 & 2 \\
\hline Spawning in deeper water & Increasing & Past 10 years & 2 & 1 \\
\hline Feeding at the surface & Decreasing & Past 40 years & 2,7 & 2 \\
\hline Size captured & Increasing & Past 10 years & 4 & 1 \\
\hline Size captured & Decreasing & Past 40 years & 2,14 & 2 \\
\hline Morphological changes (e.g., body depth) & Increasing & Past 40 years & 2,14 & 2 \\
\hline Fishing efficiency & Decreasing & Past 10 years & $2,7,10,12-15$ & 7 \\
\hline Overfishing & Increasing & Past 10 years & $2,3,4,7,9,10$ & 6 \\
\hline Different capture techniques/methods & Increasing & Past 40 years & $2,4,7$ & 3 \\
\hline Numbers and/or size of boats on ML & Increasing & Past 15 years & $3-5,10,13,15$ & 6 \\
\hline Numbers and/or size of boats on ML & Decreasing & Past 40 years & 2 & 1 \\
\hline Number of people fishing (both local and sport fishers) & Increasing & Past 30 years & 4,13 & 2 \\
\hline Number of people fishing & Decreasing & Past 5 years & 5 & 1 \\
\hline $\begin{array}{l}\text { Pollution/contamination from potential mining and human } \\
\text { activities }\end{array}$ & Increasing & Past 40 years & $1,4,5,8,13-14$ & 6 \\
\hline Water temperature & Increasing & Past 15 years & $2,7,12,14$ & 4 \\
\hline Threat of invasive species & Increasing & Past 20 years & 7 & 1 \\
\hline
\end{tabular}

because "sometimes you catch a lot and sometimes not as much -it changes year to year" (Informant 9). Finally, an increase in water temperature over the last 15 years was a concern to some (4 of 14) informants.

With a variety of concerns expressed, some informants articulated the need for increased protection or changes to current fishing practices (Table 3). In response to the idea that overfishing and the number of people fishing on the lake has increased, multiple informants expressed their desire to have local harvesting controlled. Specific examples included limiting the number of trout harvested and gillnets used during the spawning season, and setting quotas/limits for the number of fish harvested per fisher per season. With respect to sport fishers (non-Cree fishers), few informants expressed the need to limit the number of permits issued by the provincial government. Finally, most informants expressed the need to limit human activity within the Mistassini Lake watershed that could cause contamination or pollution, to safeguard Mistassini's tributaries and to reduce pollution from boats.

\section{DISCUSSION}

Diverse TEK about Mistassini lake trout among Cree fishers was consistent with previous regional research on other harvested fish species (Berkes 2012), including those within Mistassini Lake (Fraser et al. 2006, 2013). All informants described a number of locations, depths, and methods for capturing lake trout during specific times of the year, and provided details regarding the species' morphological diversity. Most informants also shared general descriptions of the locations and timing of lake trout reproduction and lake trout catches through time, and articulated several concerns regarding future conservation of the species.

\section{Similarities and differences between traditional ecological knowledge and scientific knowledge}

Broadly speaking, TEK and the scientific findings of Marin et al. (2016) were largely congruent with respect to the high amount of morphological variation, specific habitat use, and depth preferences of different lake trout forms described within Mistassini Lake. Specifically, local Cree fishing experts recognized a number of different forms based on body and head shape, coloration, and body size, and to a lesser extent, meat texture, fin accents, and spot patterns. Additionally, TEK descriptions of habitat use of different forms suggest some form-specific habitat preferences with respect to depth, spatial distribution, and specific localities within the lake (e.g., Rupert River, northern passage). Correspondingly, Marin et al. (2016) provided evidence that different habitats generate different morphological types (based on body and head shape and coloration) and nonrandom genetic relationships among lake trout from different localities. Nevertheless, interestingly, there were no specific Cree words to describe the different size and color forms depicted by informants. Lake trout were always described as namekush, with the exception of a few captured that one informant called maasimekw-namekush ("brook trout-like" lake trout). This finding is similar to that of Fraser et al. (2006), who documented that Mistassini Cree fishers described differences in brook trout appearance, movements, and spawning locations but only used the word massimekw to describe the species. Conversely, in other cases where forms are clearly visible, the same taxonomic species can be named in multiple ways (e.g., Lobel 1978, Polfus et al. 2016).

Intriguingly, informants described capturing black forms in open water at depths of 0-6 m. Yet Marin et al. (2016) found that genetic subpopulations of lake trout that were predominately black could be captured by angling in similar depths but also at even greater depths by gillnetting (Fig. 2C, Fig. 5). With some black subpopulations being more susceptible to different kinds of fishing, cryptic diversity may exist within sympatric Mistassini lake trout (e.g., biomechanical or physiological) that is not detected by coloration alone. In addition to color, multiple informants described various phenotypic differences between lake trout (e.g., size, spot pattern) and up to 28 distinguishable forms (Fig. 3). Marin et al. (2016) also detected striking phenotypic differences (three clusters based on body shape, and five clusters based on head shape). However, perhaps because of weak genetic 
population structure (global $\left.\mathrm{F}_{\mathrm{ST}}=0.017\right)$ and contemporary gene flow (global $m=0.018$ ), each one of the morphological clusters contained individuals from each one of the five genetic subpopulations (Marin et al. 2016), suggesting a highly plastic propensity of lake trout and a low cost to gene flow. Informants also described dorsal and lateral vermiculation patterns, spot pattern or intensity, fin accent coloration, scale texture, and meat color of lake trout that were not analyzed scientifically in Marin et al. (2016). Therefore, the scientific findings may underestimate the extent of phenotypic variation among Mistassini lake trout, especially given that traits such as vermiculation and spot pattern or intensity have received much less empirical attention in the scientific literature on salmonid fishes (compared to body shape and size).

Fig. 5. Proportion of individual lake trout for each genetically differentiated subpopulation (1-5) that were captured by different methods (angled versus gillnetted) in Mistassini Lake. Details about the genetic demarcation of subpopulations are described in Marin et al. (2016).

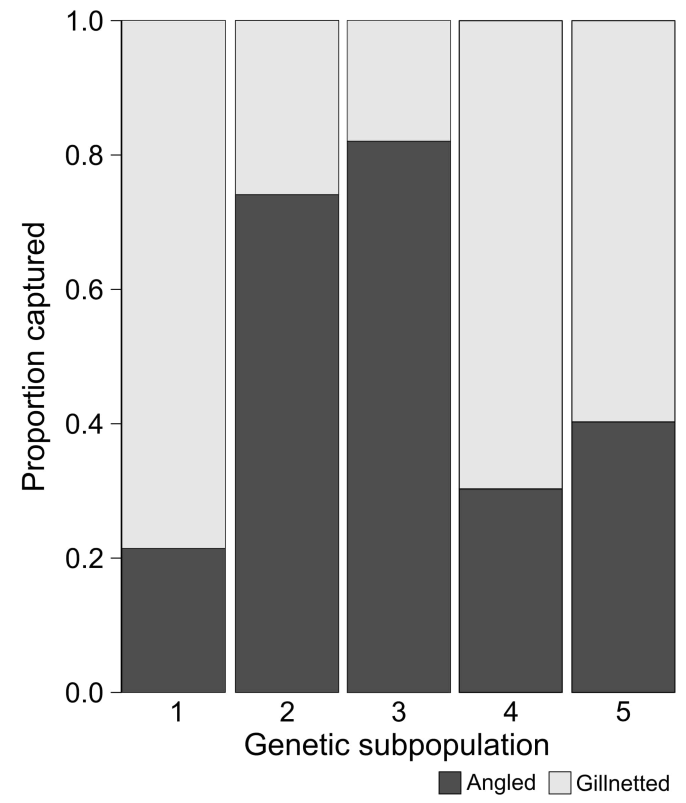

Another important aspect of our collaborative research was insight into the rarity of some forms. Unambiguously, the giant form (lake trout $>3.6 \mathrm{~kg}$ ) was described by informants as being less frequently captured and often prized. While all lake trout forms aside from the deep water form are harvested, some informants considered very large lake trout $(>9.1 \mathrm{~kg})$ undesirable for consumption whereas others favored them. Similar to other forms, informants described specific habitat and geographical locations that were more frequented by giants, with gillnets or nightlines being more effective capture methods than fishing rods. Interestingly, most giant trout habitat was described within the western basin (Fig. 1), specifically on steep drop-offs where giants could cruise up and down the water column feeding on other fish species. Consistent with the scientific findings of Marin et al. (2016), giants were less common and rarely captured via angling.
Larger lake trout were predominately assigned to one genetically defined subpopulation (\#4), but a few individual giants were also assigned to each other subpopulation (\#1-3 and 5) (Marin et al. 2016). Finally, giants were described by informants and documented upon capture as having various colors (silver, black, brown, or green-dorsal side), with a variety of morphological features (e.g., pointed snouts, fat bellies, large spots). Given the information provided through TEK and biological data, the giant form's rarity and variety of morphological variation suggest that plasticity in different genetically distinct subpopulations can generate this form.

Traditional ecological knowledge also provided key details about Mistassini Lake that allowed us to understand the nonrandom genetic patterns detected. Specifically, genetic complexes, in which lake trout were more closely related near the Rupert River mouth relative to those in the northern passage (Marin et al. 2016) (Fig. 2D), were identified as two key summer habitat preferences by informants. The Rupert River mouth is abundant in prey species, was identified by informants as "more productive," and is near multiple known spawning areas and the deepest depressions of the lake. Conversely, the northern passage ( $38 \mathrm{~km}$ away from the Rupert River mouth) was also identified by informants as important lake trout habitat but was not described in relation to prey availability or lake trout productivity. Marin et al. (2016) supports this knowledge as northern passage lake trout form a distinct subpopulation, and the authors suggest that the locality is more related to historical colonization. Indeed, Mistassini was colonized by multiple lake trout lineages (Wilson and Hebert 1998), and in other fishes (e.g., brook trout), contemporary spatial distributions of distinct forms reflect historical colonization routes of different lineages as much as ecological differences (Fraser and Bernatchez 2005a, b). Collectively, understanding the particular nuances of Mistassini Lake, including prey availability, spawning locations, geomorphology, and bathymetric idiosyncrasies helps in understanding the biological information obtained from TEK and scientific surveys (Jackson et al. 2014, Polfus et al. 2016).

At finer geographic scales, previous research has noted that TEK can provide additional and sometimes more detailed information (Huntington 1998, Neis et al. 1999, Polfus et al. 2016). For example, in Mistassini Lake, Fraser et al. (2006) documented that Cree fishers provided precise details at a finer geographic scale for brook trout because that species spawns in tributaries situated within traditional family traplines. Unlike brook trout, lake trout forage and spawn across a much larger area of Mistassini Lake, which itself can be accessed by any local Cree fisher; informants described capturing lake trout forms in many of the same general locations. Only in a few circumstances did informants provide detailed information regarding specific locations, fishing methods, gear, and timing based on a knowledge passed down from one generation to the next within a family.

Overall, given that the Cree are gregarious people, knowledge sharing is common (Fraser et al. 2006, Berkes 2012), and Mistassini Lake is a common fishing ground, it is likely that lake trout knowledge - specifically where and when to capture numerous forms - is shared among fishers. In such situations, one might expect distinct terminology to arise culturally over time to distinguish between distinct and discrete forms within harvested 
species, especially given the striking phenotypic variation described (Figs. 1 and 3, Table 2) (Marin et al. 2016). Yet, this has not happened; our specific work indicates that reproductive isolation is low among genetically distinct subpopulations for a host of reasons associated with lake trout biology (Marin et al. 2016). In other words, TEK patterns similarly hint that withinspecies diversity is present but that it is not as strong or as spatially discrete as in other cases where both TEK and western science have been conducted concurrently (Fraser et al. 2006, Polfus et al. 2014, 2016). Taken together, TEK can reveal not only distinctions within species of relevance to natural resource management and taxonomy, but can also inform the extent of such population differentiation along a continuum of "less" to "more" differentiated.

Possible factors affecting the acquisition of traditional ecological knowledge

Acquiring available TEK can be challenging for several reasons, including communication, language, or cultural issues (Huntington 2000, Usher 2000, Drew and Henne 2006). We continually consulted a variety of local community members to identify key informants for the acquisition of TEK; they represented both current and former fishing guides at local outfitting camps, and subsistence fishers. Most individuals were willing to share their knowledge once trust had been established and their confidentiality was ensured, and when they understood project objectives (see also Ferguson and Messier 1997, Fraser et al. 2006). This allowed informants to understand why TEK collation would be beneficial to all members of the local community, and resulted in informants being more likely to share TEK.

Within the local community, the extent of lake trout TEK varied among informants. Certain fishing experts possessed more knowledge about lake trout habitat and use of the lake in one particular area of the lake or season, for example. Lake trout are an important food source for Cree of Mistissini (Fraser et al. 2006), but some informants expressed more interest in other harvested fish species. For instance, brook trout were sometimes more popular to eat among certain fishers and their families, so the extent of their lake trout TEK was less detailed. Considering these factors, our study reaffirms that the incorporation of TEK requires both time and careful consideration from the commencement of a project to be effectively considered in conservation circumstances (see also Fraser et al. 2006).

\section{Access to temporal trends of lake trout through traditional ecological knowledge}

Cree fishers provided relevant information on temporal changes in the occurrence, abundance, and locations of sympatrically occurring lake trout forms in Mistassini Lake. Approximately an equal number of informants felt that lake trout abundance was either stable or declining over the last 30-40 years. Other temporal changes noted included increases in overfishing and in the number and size of fishing boats, as well as shifting capture techniques; these were felt by local Cree to negatively affect lake trout. Given the expanding human population in the Mistassini Lake region, the TEK collected and compiled here and the scientific data in Marin et al. (2016) could be used as baseline information regarding sympatric lake trout diversity and its future monitoring; any changes to the management of the species would ideally include consultation with peer-referenced, local fishing experts.

\section{CONCLUSION}

A synthesis of TEK of Mistassini lake trout that spans a four decade period strengthened what is known scientifically about the species at this geographic locale (Marin et al. 2016) and revealed the breadth of knowledge that First Nations communities may have about one of northern Canada's most important subsistence and sport fishes. Notably, Mistassini Lake harbors diverse lake trout forms that have color and body size differences and seasonal depth and spatial preferences. These distinctions and habitat preferences have direct implications for both local and sport fishers who use the lake. In particular, future lake trout conservation strategies should consider that certain subpopulations that sympatrically occur within Mistassini Lake may be more susceptible to overfishing in specific geographic locales (basins, shorelines), and that different fishing techniques target different subpopulations. The temporal perspective on harvesting and human activity trends afforded by TEK reaffirms its importance as part of multidisciplinary conservation initiatives in regions where scientific research can be conducted only sporadically. This research also demonstrates that combining TEK and biological data can provide information and ultimately understanding of often complex biological systems, especially in remote and northern regions.

Responses to this article can be read online at: http://www.ecologyandsociety.org/issues/responses. $\mathrm{php} / 9345$

\section{Acknowledgments:}

We are grateful to the kind people of Mistissini, Québec for their contribution and collaboration throughout this study. The information gained through TEK was instrumental toward the successful collection of quantitative data in Marin et al. (2016). Specifically, we thank N. Neeposh, R. Coon-Come, D. Mianscum, S. Mianscum, R. Mianscum, I. Trapper, L. Mianscum, C. Coon, J-P. Coon-Come, S. Shecapio, D. Gunner, N. Gunner, J. CoonCome, C. Blacksmith, J. Trapper, C. Mianscum, G. Poulin, E. CoonCome, R. Shecapio, and J. Coon-Come. We would also like to thank $R$. Beach for all of his fishing effort. This study would not have been possible without the guides and clients of Osprey Excursions and the clients and employees at La réserve faunique des Lacs-AlbanelMistassini-et-Waconichi. Funding for this study was provided by Niskamoon Corporation, Québec. We would like to thank the two anonymous reviewers for their excellent comments.

\section{LITERATURE CITED}

Aswani, S., and R. J. Hamilton. 2004. Integrating indigenous ecological knowledge and customary sea tenure with marine and social science for conservation of bumphead parrotfish (Bolbometopon muricatum) in the Roviana Lagoon, Solomon Islands. Environmental Conservation 31(1):69-83. http://dx.doi. org/10.1017/s037689290400116x

Berkes, F. 2012. Sacred ecology. Third edition. Taylor \& Francis, Philadelphia, Pennsylvania, USA.

Berkes, F., J. Colding, and C. Folke. 2000. Rediscovery of traditional ecological knowledge as adaptive management. 
Ecological Adaptations 10(5):1251-1262. http://dx.doi. org/10.1890/1051-0761(2000)010[1251:roteka]2.0.co;2

Braun, B. 2002. The intemperate rainforest: nature, culture, and power on Canada's west coast. First edition. University of Minnesota Press, Minneapolis, Minnesota, USA.

Brook, R. K., S. J. Kutz, A. M. Veitch, R. A. Popko, B. T. Elkin, and G. Guthrie. 2009. Fostering community-based wildlife health monitoring and research in the Canadian North. EcoHealth 6 (2):266-278. http://dx.doi.org/10.1007/s10393-009-0256-7

Cree Culture Institute. 2015. The Iiyiyuu-Iinuu - our people. http://www.creeculture.ca/content/iiyiyuu-iinuu-our-people

Davis, A., and J. R. Wagner. 2003. Who knows? On the importance of identifying "experts" when researching local ecological knowledge. Human Ecology 31(3):463-489. http://dx.doi. org/10.1023/A:1025075923297

Drew, J. A., and A. P. Henne. 2006. Conservation biology and traditional ecological knowledge: integrating academic disciplines for better conservation practice. Ecology and Society 11(2):34. http://dx.doi.org/10.5751/es-01959-110234

Dubois, A., and R. Lagueux. 1968. Comparative study of the age as determined by scales and otoliths of the lake trout (Salvelinus namaycush) of Mistassini Lake, Quebec. Naturaliste Canadien 95:907-928.

Ferguson, M. A. D., and F. Messier. 1997. Collection and analysis of traditional ecological knowledge about a population of Arctic tundra caribou. Arctic 50(1):17-28. http://dx.doi.org/10.14430/ $\underline{\operatorname{arctic} 1087}$

Fisheries and Oceans Canada (DFO). 2012. Survey of recreational fishing in Canada 2010. Ottawa, Ontario, Canada.

Fraser, D. J., and L. Bernatchez. 2005a. Adaptive migratory divergence among sympatric brook charr populations. Evolution 59(3):611-624. http://dx.doi.org/10.1554/04-346

Fraser, D. J., and L. Bernatchez. 2005b. Allopatric origins of sympatric brook charr populations: colonization history and admixture. Molecular Ecology 14(5):1497-1509. http://dx.doi. org/10.1111/j.1365-294X.2005.02523.X

Fraser, D. J., A. M. Calvert, L. Bernatchez, and A. Coon. 2013. Multidisciplinary population monitoring when demographic data are sparse: a case study of remote trout populations. Ecology and Evolution 3(15):4954-4969. http://dx.doi.org/10.1002/ $\underline{\text { ece } 3.871}$

Fraser, D. J., T. Coon, M. R. Prince, R. Dion, and L. Bernatchez. 2006. Integrating traditional and evolutionary knowledge in biodiversity conservation: a population level case study. Ecology and Society 11(2):4. http://dx.doi.org/10.5751/es-01754-110204

Gadgil, M., F. Berkes, and C. Folke. 1993. Indigenous knowledge for biodiversity conservation. Ambio 22(2-3):151-156.

Gaoue, O. G., and T. Ticktin. 2009. Fulani knowledge of the ecological impacts of Khaya senegalensis (Meliaceae) foliage harvest in Benin and its implications for sustainable harvest. Economic Botany 63(3):256-270. http://dx.doi.org/10.1007/ $\underline{\text { s12231-009-9091-6 }}$
Grand Council of the Crees (GCC). 1994. Great Whale environmental assessment: impact on fish. Vol. 2, Part A. http:// www.gcc.ca/archive/article.php?id=18

Grand Council of the Crees (GCC). 1999. Importance of neebee ("water") and neebee management in James Bay Cree territory: the need to end government marginalization of the James Bay Crees. http://www.gcc.ca/pdf/ENV000000002.pdf

Grand Council of the Crees (GCC). 2011. Cree vision of Plan Nord. http://www.gcc.ca/pdf/Cree-Vision-of-Plan-Nord.pdf

Grand Council of the Crees (GCC). 2015. About the Grand Council of the Crees (Eeyou Istchee). http://www.gcc.ca/gcc/ whogec.php

Hansen, M. J., N. A. Nate, C. C. Krueger, M. S. Zimmerman, H. G. Kruckman, and W. W. Taylor. 2012. Age, growth, survival, and maturity of lake trout morphotypes in Lake Mistassini, Quebec. Transactions of the American Fisheries Society 141(6):1492-1503. http://dx.doi.org/10.1080/00028487.2012.711263

Harris, J. 2003. Mind over mussels: rethinking Mapalane Reserve. Pages 174-181 in C. Rosen, editor. World resources 2002-2004: decisions for Earth: balance, voice and power. World Resources Institute, Washington, D.C., USA.

Henri, D., H. G. Gilchrist, and E. Peacock. 2010. Understanding and managing wildlife in Hudson Bay under a changing climate: some recent contributions from Inuit and Cree ecological knowledge. Pages 267-289 in S. H. Ferguson, L. L. Loseto, and M. L. Mallory, editors. A little less Arctic: top predators in the world's largest northern inland sea, Hudson Bay. First edition. Springer, The Netherlands. http://dx.doi.org/10.1007/978-90-481-9121-5_13

Huntington, H. P. 1998. Observations on the utility of the semidirective interview for documenting traditional ecological knowledge. Arctic 51(3):237-242. http://dx.doi.org/10.14430/ $\underline{\operatorname{arctic} 1065}$

Huntington, H. P. H. 2000. Using traditional ecological knowledge in science: methods and applications. Ecological Applications 10(5):1270-1274. http://dx.doi.org/10.1890/1051-0761 (2000)010[1270:utekis]2.0.co;2

Huntington, H. P., S. Gearheard, A. R. Mahoney, and A. K. Salomon. 2011. Integrating traditional and scientific knowledge through collaborative natural science field research: identifying elements for success. Arctic 64(4):437-445. http://dx.doi. org/10.14430/arctic4143

Inglis, J. T., editor. 1993. Traditional ecological knowledge: concepts and cases. International Program on Traditional Ecological Knowledge and International Development Research Centre, Canadian Museum of Nature, Ottawa, Ontario, Canada.

Jackson, S. E., M. M. Douglas, M. J. Kennard, B. J. Pusey, J. Huddleston, B. Harney, L. Liddy, M. Liddy, R. Liddy, L. Sullivan, B. Huddleston, M. Banderson, A. McMah, and Q. Allsop. 2014. "We like to listen to stories about fish": integrating indigenous ecological and scientific knowledge to inform environmental flow assessments. Ecology and Society 19(1):43. http://dx.doi. org/10.5751/ES-05874-190143 
Kendrick, A., and M. Manseau. 2008. Representing traditional knowledge: resource management and Inuit knowledge of barrenground caribou. Society \& Natural Resources 21(5):404-418. http://dx.doi.org/10.1080/08941920801898341

Klemetsen, A. 2010. The charr problem revisited: exceptional phenotypic plasticity promotes ecological speciation in postglacial lakes. Freshwater Reviews 3(1):49-74. http://dx.doi. org/10.1608/frj-3.1.3

Lobel, P. S. 1978. Gilbertese and Ellice Islander names for fishes and other organisms. Micronesica 14(2):177-197.

Marin, K., A. Coon, R. Carson, P. V. Debes, and D. J. Fraser. 2016. Striking phenotypic variation yet low genetic differentiation in sympatric lake trout (Salvelinus namaycush). PLoS ONE 11(9): e0162325. http://dx.doi.org/10.1371/journal.pone.0162325

McGoodwin, J. R. 2006. Integrating fishers' knowledge into fisheries science and management: possibilities, prospects, and problems. Pages 175-192 in C. R. Menzies, editor. Traditional ecological knowledge and natural resource management. University of Nebraska Press, Lincoln, Nebraska, USA.

Mehring, M., C. Seeberg-Elverfeldt, S. Koch, J. Barkmann, S. Schwarze, and S. Stoll-Kleemann. 2011. Local institutions: regulation and valuation of forest use - evidence from Central Sulawesi, Indonesia. Land Use Policy 28(4):736-747. http://dx. doi.org/10.1016/i.landusepol.2011.01.001

Menzies, C. R., and C. Butler. 2006. Understanding ecological knowledge. Pages 1-17 in C. R. Menzies, editor. Traditional ecological knowledge and natural resource management. University of Nebraska Press, Lincoln, Nebraska, USA.

Murray, G., B. Neis, C. T. Palmer, and D. C. Schneider. 2008. Mapping cod: fisheries science, fish harvesters' ecological knowledge and cod migrations in the Northern Gulf of St. Lawrence. Human Ecology 36(4):581-598. http://dx.doi. org/10.1007/s10745-008-9178-1

Mustonen, T., and P. Feodoroff. 2013. Ponoi and Näätäö River collaborative management plan. Snowchange Cooperative.

Neis, B., D. C. Schneider, L. Felt, R. L. Haedrich, J. Fischer, and J. A. Hutchings. 1999. Fisheries assessment: What can be learned from interviewing resource users? Canadian Journal of Fisheries and Aquatic Sciences 56(10):1949-1963. http://dx.doi.org/10.1139/ f99-115

Parrado-Rosselli, A. 2007. A collaborative research process studying fruit availability and seed dispersal within an indigenous community in the Middle Caquetá River region, Colombian Amazon. Ecology and Society 12(2):39. http://dx.doi. org/10.5751/es-02219-120239

Polfus, J. L., K. Heinemeyer, M. Hebblewhite, and Taku River Tlingit First Nation. 2014. Comparing traditional ecological knowledge and western science woodland caribou habitat models. Journal of Wildlife Management 78(1):112-121. http://dx.doi. org/10.1002/jwmg.643

Polfus, J. L., M. Manseau, D. Simmons, M. Neyelle, W. Bayha, F. Andrew, L Andrew, C. F. C. Klütsch, K. Rice, and P. Wilson. 2016. Łeghágots'enete (learning together): the importance of indigenous perspectives in the identification of biological variation. Ecology and Society 21(2):18. http://dx.doi. org/10.5751/ES-08284-210218

Ruiz-Mallén, I., and C. Esteve. 2013. Community-based conservation and traditional ecological knowledge: implications for social-ecological resilience. Ecology and Society 18(4):12. http://dx.doi.org/10.5751/es-05867-180412

Schindler, D. E., R. Hilborn, B. Chasco, C. P. Boatright, T. P. Quinn, L. A. Rogers, and M. S. Webster. 2010. Population diversity and the portfolio effect in an exploited species. Nature 465(7298):609-612. http://dx.doi.org/10.1038/nature09060

Stacey, N. E., J. Karam, G. Meekan, S. Pickering, and J. Ninef. 2012. Prospects for whale shark conservation in Eastern Indonesia through bajo traditional ecological knowledge and community-based monitoring. Conservation \& Society 10(1):6375. http://dx.doi.org/10.4103/0972-4923.92197

Statistics Canada. 2005. Principal lakes, elevation and area, by province and territory. http://www.statcan.gc.ca/tables-tableaux/ sum-som/101/cst01/phys05-eng.htm

Statistics Canada. 2011. NHS Aboriginal population profile, Cree Nation of Mistissini, Indian band area, Quebec, 2011. http:// www12.statcan.gc.ca/nhs-enm/2011/dp-pd/aprof/details/page.cfm? Lang $=E \&$ Geo $1=$ BAND $\&$ Code $1=630075 \&$ Data $=$ Count $\&$ SearchText $=$ Cree $\% 20$ Nation $\% 20$ of $\% 20$ Mistissini\&SearchType $=$

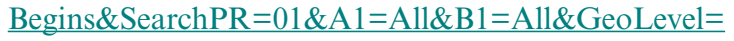
$\underline{\mathrm{PR} \& \text { GeoCode }}=630075 \& \mathrm{TABID}=1$

Taylor, E. B. 1999. Species pairs of north temperate freshwater fishes: evolution, taxonomy, and conservation. Reviews in Fish Biology and Fisheries 9(4):299-324. http://dx.doi.org/10.1023/ A:1008955229420

Thornton, T. F., and A. M. Scheer. 2012. Collaborative engagement of local and traditional knowledge and science in marine environments: a review. Ecology and Society 17(3):8. http://dx.doi.org/10.5751/es-04714-170308

Usher, P. J. 2000. Traditional ecological knowledge in environmental assessment and management. Arctic 53(2):183193. http://dx.doi.org/10.14430/arctic849

Wilson, C. C., and P. D. Hebert. 1998. Phylogeography and postglacial dispersal of lake trout (Salvelinus namaycush) in North America. Canadian Journal of Fisheries and Aquatic Sciences 55(4):1010-1024. http://dx.doi.org/10.1139/f97-286

Zimmerman, M. S., C. C. Krueger, and R. L. Eshenroder. 2007. Morphological and ecological differences between shallow- and deep-water lake trout in Lake Mistassini, Quebec. Journal of Great Lakes Research 33(1):156-169. http://dx.doi.org/10.3394/0380-1330 (2007)33[156:maedbs]2.0.co;2 